anthropologists in the United States, that the arrival of man on the American continent must be placed at a much earlier date than that hitherto generally accepted.

A communication derling with the finds, which has been issued by the Academy of Natural Sciences, quotes certain arguments put forward by Mr. Howard, for the view that man may well have lived in America 10,000 years earlier than the early Basket Makers of the south-west, who are usually dated at about 1500 B.c. He bases this view on the fact that the musk-ox, which was among the animals hunted by the population who used the early type of stone implement known as the Folsom point, is a cold weather animal which must have died out in New Mexico with the retreat of the last glacial sheet. The evidence which has been gathered recently of the early character of these stone implements is impressive, even though no absolutely conclusive evidence for the earliest dating claimed has yet been adduced. Mr. Howard supports his views by reference to the human remains of supposedly early date which have been found in America. No one, however, has as yet successfully traversed Dr. Hrdliěka's destructive criticism of their claims to high antiquity.

\section{Shetland in the Bronze Age}

Mr. A. O. CURLE's excavations on a prehistoric township at Sumburgh Ness, Shetland, on behalf of the Office of Works, an account of which appeared in the Times of September 16, convey a remarkable impression of a community which endured for a considerable period of time, remote and self-contained, but busily engaged in pastoral and industrial pursuits, and living a life, for the times, by no means squalid in its surroundings. One of the most interesting features revealed in the excavations of the season which has closed recently was the series of five elliptical chambers in the earliest of the three periods of occupation of the circular construction adjacent to the dwelling examined in a previous season. These chambers were constructed against the interior wall and opened on to a central area in which was a hearth. Some at least of these chambers had been used as workshops or storohouses. From one were taken more than forty rude stone tools of the type peculiar to Shetland, while around the hearth lay various fragments of clay moulds for making swords. As these were unused, this was evidently a place of manufacture. In the following layer of occupation, moulds for both swords and axes were found, one being a section $10 \mathrm{in}$. long, of a complete mould, still unused. The neatly paved stone or clay floors in the earlier phase of occupation, and the two boxes of slate slab in one of the chambers, nearly filled with broken bones, suggest an instinct for tidiness which is as pleasing as it is unexpected. The earliest occupation is bronze age; evidence of Hallstadt influence appears in the pottery of the second phase of occupation; and a small piece of iron slag in the third level indicates the entry of the settlement into the iron age.

\section{Racial Types in Bronze}

Museums in the United States, in order to strengthen the appeal of their anthropological collections to the public, rely to a considerable degree upon the aid of sculpture and models. The latest addition to the Field Museum, Chicago, is a hall which is devoted to the races of mankind. Here the ethnological problem is presented through the medium of a series of bronzes. The hall is named the Chauncey Keep Memorial Hall, in memory of a former trustee, the late Chauncey Keep, who died in 1929, leaving to the Museum a legacy of 50,000 dollars, which has been devoted to this purpose. Contributions towards the cost of the bronzes were made by Mr. Marshall Field, Mrs. Stanley Field, and Mrs. Charles H. Schweppe. The bronzes were executed by Malvina Hoffman, who studied her models in Africa and the Far East. There are, in all, seventyfour figures representing the principal or most characteristic types in all the continents. A considerable proportion are life-size full-length figures, the remainder heads or busts. A description of the hall and exhibits illustrated by photographs has been written by Mr. Henry Field under the title "The Races of Mankind" (Field Museum of Natural History, Anthropology, Leaflet 30) with an introduction by Sir Arthur Keith and a preface by Dr. Berthold Laufer.

\section{Metallurgical Research and Education}

DURING the recent meeting of the Iron and Steel Institute in Sheffield a large party of members visited the East Hecla Works of Messrs. Hadfields, Ltd., on September 14. Sir Robert Hadfield, chairman of the company, delivered an address which he has printed in an amplified form and abundantly illus. trated. As on similar occasions, Sir Robert has taken the opportunity of surveying a wide field of metallurgy, and in this instance he has covered the ground of metallurgical research and education, with special reference to Sheffield, in a very thorough manner. The booklet, of 106 well-printed pages, will be found valuable for reference, and many readers will be glad to see the large number of portraits, some of which are not readily accessible and must have called for much diligent search. Much of the material has appeared in the author's larger books, but is here presented in a convenient form, based on an intimate knowledge of the history of the steel industry of the district, from the primitive forge to the modern high-frequency furnace.

\section{A Famous American Engineer}

IN the July number of Mechanical Engineering, the journal of the American Society of Mechanical Engineers, Prof. J. A. Hall and Mr. G. W. Richardson give an interesting account of the life and work of George Henry Corliss (1817-1888), "one of the leading pioneers in the development of power generation from Watt to the present day". Though Corliss received no mechanical training and started life as a storekeeper, his invention, at the age of 